\title{
PENGEMBANGAN WEDUS GEMBEL (WAYANG KARDUS GEMBIRA DAN BELAJAR) SEBAGAI MEDIA MEMBANGUN JIWA NASIONALISME SEJAK DINI PADA SISWA TKK SANTO YUSUF KOTA MADIUN
}

\author{
Oktavianto Nugroho Saputro \& Soebijantoro*
}

\begin{abstract}
Abstrak
Pendidikan menjadi hal yang penting dalam kehidupan kita, melalui pendidikanah kita dapar melanjutkan kehidupan dan menatanya dengan baik untuk masa depan yang baik pula. Melalui diunia pendidikan banyak hal yang bisa didapat, tidak hanya mengenai ilmu pengetahuan, namun juga pelajaran-pelajara diluar itu. Kehidupan sosial, bagaimana kita menempatkan diri ditengah masyarakat, bersikap baik, sopan santun, cinta tanah air, semua hal tersebut juga dapat terbentuk melalui lembaga pendidikan. Semua hal yang baik dalam kehidupan ini akan lebih baik jka mulai dikenalkan sejak dini melalui lembaga pendidikan paling dasar, sebut saja PAUD. Penananman cinta tanah air dengan karakter-karakter pada anak akan lebih cepat mereka serap dan ingat jika dalam penyampaiaannya menggunakan media ajar yang menarik dan menyenangkan bagi siswa sebagai alat bantu penyampai pelajaran.
\end{abstract}

\section{Kata kunci : Media Pembelajaran, Nasionalisme, Usia Dini}

\section{Pendahuluan}

Nasionalisme adalah sebuah sikap yang seharusnya ada pada seseorang yang hidup di sebuah negara yang merdeka, dengan sikap nasionalisme yang sudah ada di setiap warga negara maka akan terwujud keamanan, kenyamanan dan kestabilan di dalam suatu negara. Namun nasionalisme ini sendiri tidak langsung dapat terlihat oleh mata, belum tentu mereka-mereka yang menggunakan pakaian bertuliskan " Aku Cinta Indonesia “ merupakan seorang nasionalis. Begitu pula sebaliknya, belum tentu juga seseorang yang tidak menggunakan atribut dengan identitas negaranya, merupakan seorang yang tidak Nasionalis.
Nasionalisme di negara ini justru tergambar jelas pada pekan olahraga, semisal pada pertandingan bola antar negara. Setiap tim memiliki supporter yang sangat banyak dan selalu hadir untuk mendukung kesebelasan yang menjadi kebanggaan negara mereka. Tidak jarang antar supporter bersitegang untuk membela martabat bangsa mereka masing-masing. Melalui hal yang demikian sangatlah terasa atmosfer nasionalisme dari warga negara itu sendiri, tidak ada yang menyuruh mereka untuk mengecat wajah mereka dengan warna bendera atau menggambar lambang negara saat melihat dan mendukung Timnas negaranya berlaga.

Dari hal-hal yang demikian Nasionalisme tampak nyata menjadi sebuah 
tindak lanjut dari sikap yang sudah tertanam untuk cinta terhadap tanah air mereka. Tidak lagi harus berperang untuk menunjukan nasionalisme itu. Saat ini bisa dilakukan dengan mengenal dan melestarikan budaya bangsa, menuntut ilmu, pembangunan, berkarya positif dan lain sebagainya untuk mengisi kemerdekaan.

Djoko Suryo (dalam Aman, 2011:35) merumuskan upaya-upaya pembangunan kembali sikap kebangsaan, yang salah satunya adalah sikap nationhood bersumber dari pengetahuan, pemahaman dan pengalaman terhadap konsep nation dan nation state. Dengan begitu nasionalisme sudah dapat dan bahkan telah diperkenalkan melalui lembaga pendidikan, mulai dari sekolah dasar hingga perguruan tinggi. Nasionalisme tidak sekedar mengajarkan tentang kenegaraan, melalui pengetahuan tentang nasionalisme ini dapat mengembangkan sikap-sikap seperti disiplin, rajin, patuh, peduli dengan sesama, gotong royong dan sikap-sikap positif lainnya.

Dunia pendidikan merupakan tempat yang paling tepat untuk memperkenalkan nasionalisme pada generasi penerus bangsa, akan lebih mudah dan dapat berkesan jika nasionalisme diperkenalkan dengan cara yang menyenangkan dan sesuai dengan perkembangan anak. Dunia anak-anak yang penuh dengan hal-hal yang menyenangkan dan mudah menerima hal-hal baru dengan cepat dan akan tertanam di memori dapat dijadikan objek yang tepat unuk memperkenalkan nasionalisme sejak dini dengan menggunakan cerita.

Penyampaian materi yang tepat diterapkan pada para siswa Taman Kanakkanak adalah menggunakan metode bercerita, seperti apa yang disampaikan oleh Isjoni (2011:90) yang menyatakan bahwa bererita mempunyai makna penting bagi perkembangan anak prasekolah/kelompok bermain.

Berdasarkan beberapa hal baik yang dapat dikembangkan melalui bercerita diatas, maka nasionalisme dapat diperkenalkan sejak dini dengan menggunakan metode bercerita yang dapat dikemas dalam bentuk yang lebih apik dan menyenangkan bagi siswa .

Dari survei awal yang dilakukan oleh peneliti di Taman Kanak-Kanak Katolik Santo Yusuf Kota Madiun, peneliti menemui adanya masalah pada anak-anak yang belajar disana. Anak-anak pada umumnya dan anak-anak di taman kanak-kank ini pada khusunya, mereka mengidolakan tokoh-tokoh superhero yang lahir di negeri paman syam.

Tokoh superhero ini yang sangat mereka kenal dan idolakan, hampir setiap anak memiliki buku, kotak pensil, tempat minum dan perlengkapan lain dengan gambar superhero tersebut. Superhero itu antaralain Avenger yang di dalamnya 
terdapat Hulk, Iron man, Thor, Captain America, Loki. Selain tokoh-tokoh itu masih banyak lagi yang merupakan superhero yang banyak di gemari banyak orang, sebut saja Spiderman, Superman dan Batman.

Kepala sekolah dari taman kanakkanak ini mengeluhkan dengan kondisi dari anak didiknya, karena mereka lebih kenal dan suka dengan cerita tokoh-tokoh dari negara lain. Beliau mengeluhkan kenapa anak-anak jaman sekarang ini hampir tidak ada yang mengenal budaya sendiri, sebut saja wayang. Karena dalam pewayangan itu juga menyuguhkan tokoh-tokoh ksatia yang tidak kalah dengan superhero yang berasal dari negara adi kuasa amerika itu.

Melalui tokoh-tokoh superhero seperti itulah, nasionalisme dapat kita perkenalkan pada anak-anak usia dini, dengan menggunakan media dan metode yang menyenangkan bagi siswa. Sekarang telah banyak lembaga pendidikan sejak dini, ada kelompok bermain, Pendidikan Anak Usia Dini (PAUD) dan taman kanak-kanak (TK). Superhero Indonesia yang dapat digunakan untuk memperkenalkan budaya Indonesia adalah wayang, kalau amerika atau marvel memiliki Avenger maka Indonesia memiliki superhero juga yang disebut pandawa. Sebut saja Hulk, sosok monster dengan tubuh berwarna hijau dan suka marah-marah, monster Indonesia dengan karakter demikian dikenal dengan nama Buto ijo.
Nasionalisme akan mudah tersampaikan jika menggunakan tokohtokoh yang heroik dan dikemas dalam sebuah bentuk dan cerita yang dikemas dengan lebih menarik dengan bantuan media pembelajaran, hal ini agar apa yang disampakan lebih mudah dimengerti dan tentu saja disukai oleh anak-anak. Tokoh pandawa misalnya, tokoh pandawa kita perkenalkan dengan karakter masingmasing dan juga di perlihatkan bentuk asli dari wayang kulitnya, agar supaya mereka tahu akan budaya wayang kulit yang dimilki oleh Indonesia. Wayang yang demikian pasti kurang menarik karena wujudnya kurang jelas.

Wayang-wayang kulit dengan bentuk asli dari masing-masing tokoh tadi di ubah dan di desain menjadi wajah animasi tanpa menghilangkan karakter dari tokoh wayang sebenarnya. Dengan begitu maka akan timbul ketertarikan dari para siswa, setelah ketertarikan sudah mulai tumbuh pada diri siswa maka tugas selanjutnya adalah menyisipkan nilai-nilai nasionalisme pada mereka. Pengenalan akan nasionalisme tidak harus melulu tentang pengetahuan kenegaraan dan kebangsaan saja. Sikap lain yang bisa ditanamkan pada siswa adalah kedisiplinan, baik pada sesama, gotong royong, suka membantu, patuh dan sikap-sikap positif lainnya.

Wayang yang digunakan sebagai media pengenalan nasionalisme ini sendiri haruslah terbuat dari bahan yang dikenal 
dan diketahui oleh anak-anak. Bahan kertas dapat dijadikan alternatif pemilihan bahan baku dari wayang ini. Tokoh yang diperkenalkan pun tidak terbatas pada tokoh pewayangan seperti pandawa saja, tokoh pejuang seperti Bung Karno dan kawan-kawan pun bisa dikemas dalam bentuk wayang.

Penerapan media wayang sebagai sarana mengembangkan Nasionalisme ini akan peneliti lakukan di TKK Santo Yusuf Kota Madiun. TKK Santo Yusuf merupakan taman kanak-kanak yang bonafit di kota madiun dan di favoritkan sebagai tempat belajar untuk anak-anak. Fasilitas yang memadai dan kualitas pengajar yang baik menjadikan anak didik yang berkualitas pula dalam perkembangannya.

Ketersediaan fasilitas yang baik dan pengajar yang baik ini membuat taman kanak-kanak ini menjadi sebuah paket yang lengkap dan bisa dibilang sempurna sebagai tempat anak-anak untuk belajar dan berkembang. Tak ada gading yang tak retak, begitu pula dengan apa yang ada di TKK Santo Yusuf ini. Peneliti menemui adanya masalah dalam observasi awal di taman kanak-kanak ini, kekurangannya terletak pada siswa TKK santo yusuf yang kurang mengenal dan mengetahui tentang budaya bangsa yang merupakan identitas nasional.

$$
\text { Pengenalan budaya dan }
$$

penanaman nasionalisme hendaknya sudah dilakukan sejak dini pada generasi penerus bangsa. Anak-anak dengan karakter yang masih senang bermain ini dapat dimaksimalkan jika pada saat bermain mereka belajar. Melalui dunia pendidikanlah nasionalisme dapat mulai diperkenalkan dengan menggunakan media yang menarik sesuai perkembangan anak. Media yang diharapakan oleh peneliti dapat memperkenalkan dan mengembangkan nasionalisme sejak dini ini diberi nama WEDUS GEMBEL yang merupakan akronim dari wayang kardus gembira dan belajar.

\section{Identifikasi masalah}

Peneliti yang telah melaksanakan observasi awal mendapati adanya permasalahan yang ada pada siswa taman kanak-kanak yang dieluhkan oleh kepala sekolah. Masalah tersebut antaralain :

1. Para siswa lebih mengenal tokoh-tokoh super hero yang berasal dari negara lain dan menjadikan super hero tersebut sebagai idolanya, yang mengakibatkan anak-anak hampir tidak mengenal budaya dari negaranya dan kurangnya pemahaman tentang cinta tanah air.

2. Kepala sekolah sangat menyayangkan anak didiknya di sekolah tidak mengenal budaya yang ada di negara ini, sebut saja wayang. Wayang yang merupakan budaya bangsa ini dinilai dapat memberi pelajaran pada mereka tentang budaya, tata krama, budi pekerti dan hal-hal yang baik dan bahkan bisa memperkenalkan mereka mengenai nasionalisme dan cinta tanah air.

\section{Pembatasan Masalah}


dari masalah yang telah ditemui oleh peneliti pada observai awal, maka permasalahan yang akan dikaji dalam penelitian ini adalah sebagai berikut :

1. Pengembangan media pembelajaran yang dapat digunakan sebagai sarana menumbuhkembangan sikap nasionalisme sejak dini.

2. Media yang digunakan bernama WEDUS GEMBEL yang merupakan akronim dari WAYANG KARDUS GEMBIRA DAN BELAJAR.

3. Penelitian dilakukan di Taman KanakKanak Santo Yusuf Kota Madiun.

\section{Rumusan Masalah}

Berdasarkan latar belakang masalah, identifikasi masalah dan pembatasan masalah di atas, maka dapat dirumuskan masalahnya sebaagai berikut : Apakah media WEDUS GEMBEL (WAYANG KARDUS GEMBIRA DAN BELAJAR) dapat mengembangkan jiwa nasionalisme sejak dini pada siswa taman kanak-kanak katolik Santo Yusuf Kota Madiun?

\section{Tujuan Penelitian}

Berdasarkan rumusan masalah di atas, maka penelitian ini bertujuan untuk mengetahui keefektifan media WEDUS GEMBEL (WAYANG KARDUS GEMBIRA DAN BELAJAR) dalam hal mengembangkan jiwa nasionalisme sejak dini pada siswa Taman Kanak-Kanak Katolik Santo Yusuf Kota Madiun.

\section{Kegunaan Penelitian}

Dengan adanya penelitian ini diharapkan hasilnya dapat bermanfaat dalam 2 aspek, yang antara lain :

1. Manfaat teoritis

Penelitian ini akan menghasilkan sebuah media yang dapat digunakan untuk memperkenalkan budaya Indonesia dan Nasionalisme pada siswa taman kanak-kanak. Media yang dihasilkan juga dapat dimanfaatkan sebagai alat peraga oleh para tenaga pendidik untuk mengajak para siswa belajar sambil bermain, dengan begitu pengetahuan tentang Nasionalisme dapat tersampaikan dengan baik.

2. Manfaat praktis

Penelitian ini dapat memberikan pengetahuan pada semua pihak masyarakat, terutama orang tua akan pentingnya memberikan pengertian sejak dini pada anak-anaknya mengenai nasionalisme. Dengan begitu anak-anak akan tumbuh dan berkembang menjadi pribadi yang bangga akan budaya bangssanya.

\section{Spesifikasi Produk yang Dikembangkan} Media WEDUS GEMBEL (WAYANG KARDUS GEMBIRA DAN BELAJAR) ini disajikan dengan terlebih dahulu bercerita tentang tokoh-tokoh pewayangan di Indonesia, yang pada dasarnya memeliki karakter hampir sama dengan super hero Amerika. Misalnya Gatot Kaca, Gatot Kaca memiliki karakter yang hampir sama 
dengan Iron Man yaitu otot kawat tulang besi dan dapat terbang tanpa bantuan sayap layaknya sepekor burung. Begitu pula dengan Pandawa yang bisa disamakan dengan Avengers, hal ini dilakukan agar anak-anak dapat mengikuti arah dari cerita pewayangan yang di ceritakan.

Wayang dengan bentuk yang menarik akan memancing rasa ingin tahu siswa, bahan yang digunakan untuk membuat media pun kerbuat dari kertas. Anak-anak yang mengetahui dari apa wayang ini dibuat maka membuat mereka berimajinasi untuk dapat membuatnya sendiri, karena bahan yang dipakai sangat mudah ditemui.

Media wayang ini akan menjadi lengkap saat cerita yang dibawakan beraasal dari buku-buku cerita yang mengandung cerita rakyat dan nasionalisme ini dapat menambah ketertarikan para siswa untuk mendengarkan cerita dan semakin ingin tahu banyak mengenai tokohtokoh pewayangan yang merupakan budaya Indonesia. Tokoh-tokoh pewayangan Indonesia ternyata tidak kalah menarik dengan film-film super hero Amerika bila disampaikan dengan cara yang kreatif dan menyenangkan.

\section{Asumsi dan Keterbatasan \\ Pengembangan}

Media WEDUS GEMBEL ini diharapkan dapat digunakan sebagai alat untuk memperkenalkan budaya Indonesia dan mengembangkan nasionalisme sejak dini pada TKK Santo Yusuf Kota Madiun. Media yang merupakan modifikasi dari wayang ini diharapkan dapat membuat suasana belajar yang menyenangkan dan dapat diterima oleh siswa taman kanakkanak.

Pembelajaran yang sesuai untuk diterapkan pada siswa taman Kanak-kanak telah diungkapkan oleh Hamalik (dalam Itadz,2008:16) pendidikan untuk anak usia dini,khususnya untuk anak-anak si taman Kanak-kanak, harus memperhatikan beberapa prinsip pendidikan, antara lain sebagai berikut:

1. TK merupakan salah satu bentuk awal pendidikan sekolah. Untuk itu, TK perlu menciptakan situasi pendidikan yang dapat memberikan rasa aman dan menyenangkan.

2. Masing-masing anak perlu memperoleh perhatian yang bersifat individual, sesuai dengan kebutuhan anak-anak usia TK.

3. Perkembangan adalah hasil proses kematangan dan proses belajar.

4. Kegiatan belajar di TK adalah pembentukan perilaku melalui pembiasan yang terwujud dalam kegiatan sehari-hari.

5. Sifat kegiatan belajar di TK merupakan pengembangan kemampuan yang telah diperoleh di rumah. 
6. Bermain merupakan cara yang paling baik untuk mengembangkan kemampuan anak.

Beberapa prinsip yang telah dipaparkan diatas maka jika dikaikan dengan media WEDUS GEMBEL (Wayang Kardus Gembira dan Belajar) maka media ini dapat dikatakan sebagai sebuah media yang tepat digunakan pada siswa taman Kanak-kanak. Hal ini dikarenakan media tersebut merupakan media yang dapat disampaikan dengan cara yang menyenangkan, aman bagi siswa dan dapat digunakan untuk menanamkan pendidikan karakter yang dapat dikembangkan sesuai dengan kegiatan sehari-hari dirumah.

\section{Tinjauan Pustaka}

\section{Media Pembelajaran}

Dunia pendidikan selalu menjadi hal yang sangat diperhatikan, karena melalui pendidikanlah akan muncul generasi-generasi baru yang piawai, cerdas, pintar yang nantinya diharapkan dapat menjadi sosok yang berguna bagi diri sendiri, masyarakat, bangsa dan negara. Maka dalam penyampaian segala materi dalam kegiatan belajar mengajar haruslah dapat tersampaikan dengan baik dan ada perubahan sikap yang positif.

$$
\text { Azhar Arsyad }
$$

menyatakan bahwa Kata media berasal dari bahasa latin medius yang secara harfiah berarti 'tengah', 'perantara', 'pengantar'. Dalam bahasa Arab media adalah perantara atau pengantar pesan dari pengirim kepada penerima pesan. Hal serupa yang menJelaskan bahwa media adalah perantara disampaikan oleh Yudhi Munadi (2008:7) bahwa media adalah segala sesuatu yang dapat menyampaikan dan menyalurkan pesaN dari sumber secara terencana sehingga tercipta lingkungan belajar yang kondusif dimana penerimanya dapat melakukan proses belajar secara efektif dan efisien.

Dari uraian tentang pengertian dan definisi mengenai media pembelajaran diatas, maka dapat disimpulkan bahwa pengertian mengenai Media pembelajaran adalah alat yang digunakan untuk menyampaikan pesan dari sumber informasi ke penerima pesan dalam proses pembelajaran yang berlangsung antara pendidik dan peserta didik dengan tujuan agar materi yang disampaikan dapat dengan mudah dimengerti oleh peserta didik dan menciptakan suasana yang menyenagkan.

\section{Nasionalisme}

Nasonalisme berasal dari kata latin 'natio' yang berati lahir atau kelahiran. Dalam proses perkembangan kebudayaan dan peradaban bangsa-bangsa di dunia, kata natio dalam bahasa latin lalu berkembang kedalam sejumlah bahasa termasuk bahasa inggris dan diartikan dengan nation. seperti yang dikemukakan oleh Muhammad Imarah (dalam Aman, 2011:38) "cinta tanah air atau nasionalisme adalah fitrah asli manusia dan sama dengan kematian". 
Anthony D. Smith (2003: 10) yang menyatakan bahwa "Nasionalisme adalah suatu ideologi yang meletakkan bangsa di pusat masalahnya dan berupaya mempertinggi keberadaanya". Sedangkan Hans Kohn (dalam Aman, 2011:38) "Nationalism is a state of mind in which the supreme loyalty of individual is felt to be due the nation state." Bahwa nasionalisme merupakan suatu paham yang memandang bahwa kesetiaan tertinggi individu harus diserahkan kepada negara kebangsaan.

\section{Metode Penelitian}

Metode penelitian yang digunakan adalah metode Penelitian dan Pengembangan (Research and Development). Karena metode penelitian ini digunakan untuk menghasilkan suatu produk berupa media WEDUS GEMBEL (Wayang Kardus Gembira Dan Belajar) dan menguji keefektifan produk tertentu.

Menurut Sugiyono (2010: 407) penelitian dan pengembangan adalah metode penelitian yang digunakan untuk menghasilkan tertentu dan menguji keefektifan produk tersebut.

\section{Prosedur Pengembangan}

Dalam penelitian ini digunakan tahap-tahap penelitian pengembangan Research and Development (R\&D). Prosedur pengembangan akan memaparkan prosedur yang ditempuh oleh peneliti dalam membuat produk. Dalam prosedur pengembangan, peneliti menyebut sifat-sifat komponen pada setiap tahapan dalam pengembangan produk, dan menjelaskan hubungan antar komponen dalam sistem.

Langkah-langkah Research and Development (R\&D) dalam pengembangan media pembelajaran (Sugiono, 2010:408) sebagai berikut:

1. Potensi dan Masalah

Potensi adalah segala sesuatu yang bila didayagunakan akan memiliki nilai tambah. Sebagai contoh, dalam bidang sosial dan pendidikan, misalnya kita punya potensi penduduk usia kerja yang cukup banyak, sehingga melalui model pembelajaran tertentu dapat diberdayakan sebagai tenaga kerja pertanian atau industri yang berbasis bahan mentah alam Indonesia.

Masalah adalah penyimpangan antara yang diharapkan dengan yang terjadi. Salah satu masalah yang muncul pada siswa Taman kanak-Kanak Santo Yusuf Kota Madiun adalah kurangnya pemahaman akan budaya bangsa dan sikap nasionalisme. Masalah ini dapat diatasi melalui Research and Development (R\&D) dengan cara meneliti sehingga ditemukan media pembelajaran yang efektif untuk memperkenalkan budaya bangsa dan nasionalisme sejak dini dengan cara yang menyenangkan.

Data tentang potensi dan masalah tidak harus dicari sendiri, tetapi bisa berdasarkan laporan 
penelitian orang lain, atau dokumentasi laporan kegiatan dari perorangan atau instansi tertentu yang masih up to date.

2. Mengumpulkan Informasi Informasi yang telah terkumpul dapat digunakan sebagai bahan untuk perencanaan produk tertentu yang diharapkan dapat mengatasi masalah tersebut. Dalam tahap ini diperlukan metode penelitian tersendiri. Metode apa yang akan digunakan untuk penelitian tergantung permasalahan dan ketelitian tujuan yang ingin dicapai.

3. Desain produk

Produk yang dihasilkan dalam penelitian Research and Development bermacam-macam, salah satunya dalam bidang pendidikan. Dalam bidang pendidikan ,produk-produk yang dihasilkan melalui $R \& D$ diharapkan dapat meningkatkan produktivitas pendidikan, yaitu lulusan yang jumlahnya banyak, berkualitas, dan relevan dengan kebutuhan.

4. Validasi Desain

Validasi Desain merupakan proses kegiatan untuk menilai apakah rancangan produk, dalam hal ini metode mengajar baru secara rasional akan lebih efektif dari yang lama atau tidak. Dikatakan secara rasional, karena validasi disini masih bersifat penilaian berdasarkan pemikiran rasional, belum fakta lapangan.

5. Perbaikan Desain
Setelah desain produk, divalidasi melalui diskusi pakar dan para ahli lainnya, maka akan diketahui kelemahannya. Kelemahan tersebut selanjunya dicoba untuk dikurangi dengan cara memperbaiki desain.

6. Uji Coba Produk

Uji Coba Produk dilakukan dengan tujuan untuk mendapakan informasi apakah metode mengajar baru tersebut lebih efektif dan efisien dibandingkan dengan metode mengajar yang lama atau yang lain.

7. Revisi Produk

Revisi produk dilakukan agar kreatifitas murid dalam belajar dapat meningkat pada gradasi yang tinggi. Setelah direvisi, maka perlu diujicobakan lagi kelas yang lebih luas.

8. Uji Coba Pemakaian

Produk yang berupa metode baru tersebut diterapkan dalam lingkup lembaga pendidikan yang luas. Dalam operasinya, metode baru tersebut, tetap harus dinilai kekurangan atau hambatan yang muncul guna perbaikan lebih lanjut.

9. Revisi Produk

Revisi produk ini dilakukan, apabila dalam pemakaian dalam lembaga pendidikan yang lebih luas terdapat kekurangan dan kelemahan. Dalam uji coba pemakaian, sebaiknya pembuat produk selalu mengevaluasi 
bagaimana kinerja produk dalam hal ini adalah metode mengajar.

10. Pembuatan Produk masal

Pembuatan produk masal ini dilakukan apabila produk yang telah diujicobakan dinyatakan efekif dan layak untuk diproduksi masal.

\section{Uji Coba Produk}

1. Desain Produk

Desain uji coba yang digunakan dalam penelitian pengembangan disesuaikan dengan prosedur penelitian pengembangan Research and Development ( $R \& D)$ menurut sugiyono, yang digambar sesuai diagram berikut:

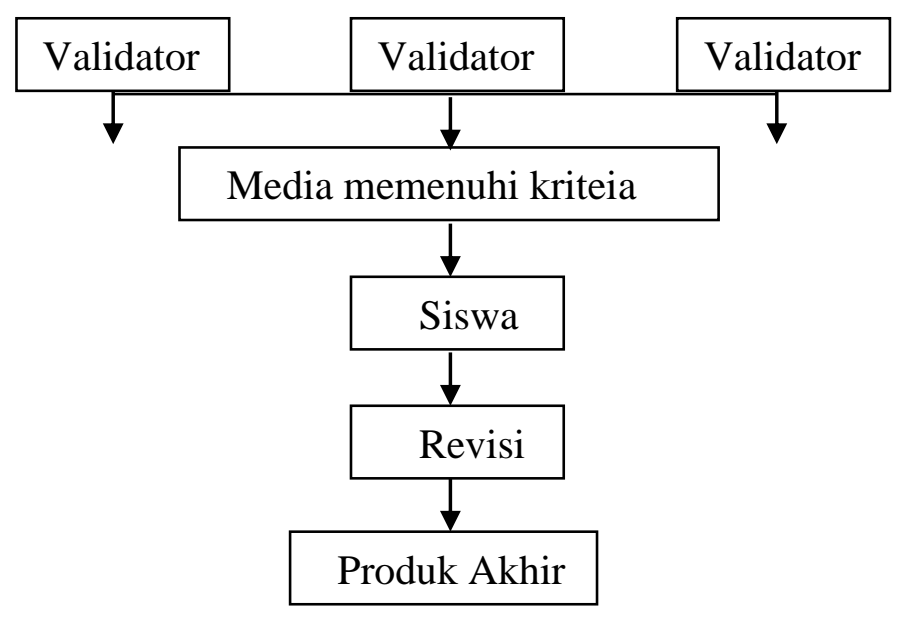

Gambar 3.1 Desain Uji Coba Setelah mendapat validasi dari validator maka dilakukann revisi sampai validator menyatakan media yang dibuat mempunyai kriteria baik. Selanjutnya media dapat diujicobakan kepada siswa sebagai user. Pada tahap ini siswa dimintai tanggapan dan respon tentang produk yang telah dibuat.masukan yang diperoleh digunakan sebagai bahan untuk direvisi sampai produk akhir.

2. Subjek Uji Coba

Penelitian pengembangan media ini mengambil subjek uji coba siswa Taman Kanak-Kanak Santo Yusuf Kota Madiun.

3. Jenis data

Jenis data yang dapat diambil dalam peneliian pengembangan ini adalah data yang berasal dari ketiga validator, data observasi terhadap penerapan media WEDUS GEMBEL (Wayang Kardus Gembira dan Belajar).

4. Instrument Pengumpulan Data

Instrument penelitian yang digunakan dalam penelitian ini adalah sebagai berikut:

a. Lembar Validasi Media pembelajaran

Lembar validasi media digunakan untuk mengetahui tingkat kelayakan media pembelajaran yang dikembangkan sebelum dilakukan pengujian langsung di kelas. Uji kelayakan media pembelajaran yang dikembangkan ini dilakukan oleh validator, yang mana terdiri dari dosen pembimbing dan kepala sekolah TKK Santo Yusuf Kota Madiun.

Lembar validasi tersebut dibuat dengan menggunakan skala bertingkat. Skala pengukuran 
dengan tipe ini, akan didapat dengan interval nilai 1-5 yaitu:

5 = Sangat Baik, jika pernyataan dilaksanakan sangat baik dan sesuai fakta;

$4=$ Baik, jika pernyataan dilaksanakan dengan baik dan sesuai fakta;

Lembar validasi media WEDUS GEMBEL (Wayang Kardus Gembira dan Belajar) terdiri dari 6 item yang harus dinilai,jumlah skor maksimalnya adalah 30 (lampiran 1). Penilaian dilakukan dengan memberi tanda centang $(\sqrt{ })$ pada
3 = Cukup Baik, jika pernyataan dilaksanakan dengan baik;

2 = Kurang Baik, jika pernyataan dilaksanakan kurang baik;

1 = Tidak Baik, jika pernyataan dilaksanakan idak baik dan tidak sesuai fakta.

kolom yang paling sesuai dengan penilaian yang diberikan oleh validator. Kisi-kisi lembar jawaban media WEDUS GEMBEL (Wayang Kardus Gembira dan Belajar) sebagai berikut:

Tabel 3.1 Kisi-kisi Lembar Validasi

\begin{tabular}{|l|l|}
\hline No & \multicolumn{1}{|c|}{ Aspek yang dinilai } \\
\hline 1 & Media pembelajaran yang dikembangkan terbuat dari bahan dasar kardus. \\
\hline 2 & Media pembelajaran yang dikembangkan merupakan produk baru. \\
\hline 3 & $\begin{array}{l}\text { Media pembelajaran yang dikembangkan sudah memenuhi prinsip-prinsip } \\
\text { pengembangan media. }\end{array}$ \\
\hline 4 & Bentuk media pembelajaran menarik bagi siswa \\
\hline 5 & $\begin{array}{l}\text { Media pembelajaran yang dikembangkan sesuai dengan materi yang akan } \\
\text { disampaikan. }\end{array}$ \\
\hline 6 & $\begin{array}{l}\text { Media pembelajaran yang dikembangkan mampu mengembangkan jiwa } \\
\text { nasionalisme peserta didik }\end{array}$ \\
\hline
\end{tabular}

b. Lembar Observasi

Observasi dialakukan sesuai dengan kebutuhan penelitian mengingat tidak setiap penelitian menggunakan alat pengumpul data demikian. Observasi adalah pengamatan yang dilakukan secara sengaja, sistematis mengenai fenomena sosial dengan gejalagejala psikis untuk kemudian dilakukan pencatatan (Joko
Subagyo,2004:63). Lembar observasi ini digunakan untuk mengetahui reaksi para siswa terhadap media WEDUS GEMBEL (Wayang Kardus Gembira dan Belajar). Lembar obseravasi ini digunakan pada saat melakukan uji coba penerapan media pembelajaran kepada siswa. Lembar observasi ini terdiri dari 5 point yang harus dinilai dengan skor 
maksimal 20. Kisi-kisi lembar

observasi sebagai berikut:

Tabel 3.2 Kisi-kisi Lembar

Observasi

\begin{tabular}{|l|l|}
\hline No & \multicolumn{1}{|c|}{ Aspek yang dinilai } \\
\hline 1 & Kedisiplinan \\
\hline 2 & Semangat belajar \\
\hline 3 & Keberanian siswa \\
\hline 4 & Keaktifan siswa \\
\hline 5 & Pemahaman siswa \\
\hline
\end{tabular}

5. Teknik Analisis Data

a. Analisis Data Validasi Media

Validasi media pembelajaran yang dibuat didasarkan pada data lembar kelayakan media yang berasal dari ketiga validator yang dipilih. Validasi media diperlukan untuk menguji kevalidan media yang dibuat.

Tabel 3.3 Kriteria kevalidan Media berdasarkan persentase

\begin{tabular}{|c|c|c|}
\hline No & Presentase & Kriteria \\
\hline 1 & $85-100$ & Valid \\
\hline 2 & $65-84$ & Cukup valid \\
\hline 3 & $45-64$ & Kurang valid \\
\hline 4 & $25-44$ & Tidak valid \\
\hline
\end{tabular}

Untuk memperoleh nilai dari validator menggunakan rumus sebagai berikut:

$\mathrm{x}=$ Skor yang diperoleh $\mathrm{x} 100$ Skor Maksimal

b. Analisis Lembar Observasi

Analisis lembar observasi digunakan untuk menghitung data hasil observasi peneliti selama kegiatan pembelajaran berlangsung.
Rumus analisis lembar observasi yang digunakan sebagai berikut:

$\mathrm{NA}=\mathrm{Ni} \times 4$

Keterangan:

$\mathrm{NA}=$ Nilai akhir

$\mathrm{Ni}=$ Nilai yang didapat siswa

Hasil penilaian:

$0-20=$ Tidak baik

21-40 = Kurang baik

41-60 = Cukup baik

$61-80=$ Baik

$81-100=$ Sangat baik

\section{Hasil Penelitian}

Penelitian pengembangan media WEDUS GEMBEL (Wayang Kardus Gembira dan Belajar) ini dilaksanakan pada tanggal 9 Mei 2014 yang bertempat di Taman KanakKanak Katolik Santo Yusuf Kota Madiun. Dalam penelitian ini dilaksanakan uji coba produk kepada siswa yang menjadi subyek dari penelitian ini adalah para siswa kelas B3 dengan jumlah siswa sebanyak 19 siswa, sebagaimana tercantum dalam tabel berikut: 
Tabel 4.1 Daftar Siswa Kelompk B3 TKK Santo Yusuf Kota Madiun

\begin{tabular}{|c|c|c|}
\hline $\begin{array}{c}\text { No } \\
\text { Absen }\end{array}$ & Nama & $\begin{array}{l}\text { Jenis } \\
\text { Kelamin }\end{array}$ \\
\hline 1 & 2 & 3 \\
\hline 1 & $\begin{array}{l}\text { Amelia Sweesta } \\
\text { Puspitasari }\end{array}$ & $P$ \\
\hline 2 & Andreas Santoso & $\mathrm{L}$ \\
\hline 3 & $\begin{array}{l}\text { Antonis Bagas } \\
\text { Boris Pranaya }\end{array}$ & $\mathrm{L}$ \\
\hline 4 & $\begin{array}{l}\text { Anthena } \\
\text { Alexandra } \\
\text { Wibisono }\end{array}$ & $\mathrm{P}$ \\
\hline 5 & $\begin{array}{l}\text { Calista Cattleya } \\
\text { Victory } \\
\text { Johanesia }\end{array}$ & $\mathrm{P}$ \\
\hline 6 & $\begin{array}{l}\text { Cristophorus } \\
\text { Jovaldy } \\
\text { Octavianus D }\end{array}$ & $\mathrm{L}$ \\
\hline 7 & $\begin{array}{l}\text { Gilbertus } \\
\text { Ronaldo Gofar }\end{array}$ & $\mathrm{L}$ \\
\hline 8 & $\begin{array}{ll}\text { Jessica } & \text { Emily } \\
\text { Tjahjono } & \\
\end{array}$ & $\mathrm{P}$ \\
\hline 9 & $\begin{array}{l}\text { Meidyssa } \\
\text { Eveluna }\end{array}$ & $\mathrm{P}$ \\
\hline 10 & $\begin{array}{ll}\text { Michelle } & \text { Olivia } \\
\text { Nathalia } & \\
\end{array}$ & $\mathrm{P}$ \\
\hline 11 & $\begin{array}{l}\text { Nabela } \\
\text { Wahyuningsih }\end{array}$ & $P$ \\
\hline 12 & $\begin{array}{l}\text { Radya Pitaloka } \\
\text { Harwi Fortnasari }\end{array}$ & $\mathrm{P}$ \\
\hline 13 & $\begin{array}{l}\text { Stevin Sherona } \\
\text { Ageuma }\end{array}$ & $\mathrm{P}$ \\
\hline 14 & $\begin{array}{l}\text { Thomas Kevin } \\
\text { Widodo }\end{array}$ & $\mathrm{L}$ \\
\hline 15 & $\begin{array}{l}\text { Valentino } \\
\text { Radithya } \quad \text { Deo } \\
\text { Ganendra }\end{array}$ & $\mathrm{L}$ \\
\hline 16 & $\begin{array}{l}\text { Yehuda Pratama } \\
\text { Setya Hadi }\end{array}$ & $\mathrm{L}$ \\
\hline 17 & $\begin{array}{ll}\text { Yerriel } & \text { Mosses } \\
\text { Bawole } & \\
\end{array}$ & $\mathrm{L}$ \\
\hline 18 & $\begin{array}{l}\text { Yoel Abimanyu } \\
\text { Nugroho }\end{array}$ & $\mathrm{L}$ \\
\hline 19 & $\begin{array}{l}\text { Yoselin Angelina } \\
\text { Setiawan }\end{array}$ & $\mathrm{P}$ \\
\hline
\end{tabular}

dilaksanakan selama waktu yang telah disebutkan diatas oleh peneliti, diperoleh data penelitian dari hasil lembar observasi yang dilakukan oleh peneliti selama kegiatan uji coba produk. Uji coba produk dilaksanakan sebanyak satu kali, uji coba produk 1. Data-data yang diperoleh oleh peneliti selama proses penelitan dipaparkan secara lengkap sebagai berikut:

1. Data Hasil Pengamatan atau Observasi a. Uji Coba Produk 1

Data hasil pengamatan atau observasi ini merupakan data yang diperoleh peneliti selama kegiatan uji coba produk kepada siswa kelompok B3 yang dilaksanakan di TKK Santo Yusuf Kota Madiun, yang bertujuan untuk mengetahui bagaimanakah reaksi para siswa pada saat mengikuti pelajaran yang disampaikan dengan adanya media WEDUS GEMBEL (Wayang Kardus Gembira dan Belajar) dalam membangun jiwa nasionalisme.

Data yang diperoleh peneliti yang di dasarkan pada pengamatan yang dilakukan dalam pembelajaran saat uji coba produk satu. Proses pengamatan dan penilaian berdasar pada kelima aspek yang akan diobservasi dinilai langsung oleh Ibu Agnes selaku kepala sekolah TKK Sano Yusuf Kota Madiun, dan peneliti berperan sebagai penyampai materi dengan menggunakan media WEDUS GEMBEL (Wayang Kardus Gembira dan Belajar). Dari proses pembelaaran 
tersebut didapatkan hasil sebagai berikut:

Tabel 4.2 Data hasil observasi Uji Coba Produk 1 Kelompok B3 TKK

Santo Yusuf Kota Madiun

\begin{tabular}{|c|c|c|c|c|c|c|c|c|}
\hline \multirow[t]{2}{*}{ No } & \multirow[t]{2}{*}{ Nama } & \multicolumn{5}{|c|}{$\begin{array}{c}\text { Aspek } \\
\text { Pengamatan } \\
\end{array}$} & \multirow[t]{2}{*}{ Skor } & \multirow[t]{2}{*}{ Total } \\
\hline & & A & $\mathrm{B}$ & $\mathrm{C}$ & $\mathrm{D}$ & $\mathrm{E}$ & & \\
\hline 1 & 2 & \multicolumn{5}{|c|}{3} & 4 & 5 \\
\hline 1. & Amelia Sweesta Puspitasari & 4 & 4 & 4 & 4 & 4 & 20 & 100 \\
\hline 2. & Andreas Santoso & 4 & 4 & 4 & 4 & 4 & 20 & 100 \\
\hline 3. & Antonis Bagas Boris Pranaya & 3 & 4 & 3 & 4 & 4 & 18 & 90 \\
\hline 4. & Anthena Alexandra Wibisono & 4 & 4 & 4 & 4 & 4 & 20 & 100 \\
\hline 5. & Calista Cattleya Victory J & 4 & 4 & 4 & 4 & 4 & 20 & 100 \\
\hline 6. & Cristophorus Jovaldy O. D & 4 & 4 & 4 & 4 & 4 & 20 & 100 \\
\hline 7. & Gilbertus Ronaldo Gofar & 4 & 4 & 4 & 4 & 4 & 20 & 100 \\
\hline 8. & Jessica Emily Tjahjono & 4 & 4 & 4 & 4 & 4 & 20 & 100 \\
\hline 9. & Meidyssa Ayu Eveluna & 4 & 4 & 4 & 4 & 4 & 20 & 100 \\
\hline 10. & Michelle Olivia Nathalia & 3 & 4 & 3 & 4 & 3 & 17 & 85 \\
\hline 11. & Nabela Wahyuningsih & 4 & 4 & 4 & 4 & 4 & 20 & 100 \\
\hline 12. & Radya Pitaloka Harwi F & 4 & 4 & 4 & 4 & 4 & 20 & 100 \\
\hline 13. & Stevin Sherona Ageuma & 4 & 4 & 4 & 4 & 4 & 20 & 100 \\
\hline 14. & Thomas Kevin Widodo & 3 & 4 & 4 & 4 & 4 & 19 & 95 \\
\hline 15. & Valentino Radithya Deo G & 4 & 4 & 4 & 4 & 4 & 20 & 100 \\
\hline 16. & Yehuda Pratama Setya Hadi & 4 & 4 & 4 & 4 & 4 & 20 & 100 \\
\hline 17. & Yerriel Mosses Bawole & 3 & 4 & 3 & 4 & 3 & 17 & 85 \\
\hline 18. & Yoel Abimanyu Nugroho & 4 & 4 & 4 & 4 & 4 & 20 & 100 \\
\hline 19. & Yoselin Angelina Setiawan & 4 & 4 & 4 & 4 & 4 & 20 & 100 \\
\hline
\end{tabular}

Keterangan :

Rumus :

$\mathrm{NA}=\mathrm{Ni} \times 5$.

$\mathrm{A}=$ Kedisiplinan

$\mathrm{B}=$ Semangat belajar

$\mathrm{C}=$ Keberanian siswa

$\mathrm{D}=$ Keaktifan siswa

$\mathrm{E}=$ Pemahaman siswa

Berdasarkan data pada tabel 4.2

\section{Hasil Pengembangan}

maka dapat disimpulkan bahwa respon siswa terhadap penggunaan media WEDUS GEMBEL (Wayang Kardus Gembira dan Belajar) bisa dibilang sangat baik. Hal ini ditunjukan dengan nilai yang berada antara 60-100, yang mana 4 anak mendapat nilai antara 61-80 dengan kriteria baik, dan 15 anak sisanya mendapat nilai 81-100 dengan kriteria sangat baik.

Model pengembangan yang digunakan dalam penelitian ini adalah model (Research and Development). Langkah-langkah Research and Development (R\&D) dalam pengembangan media pembelajaran (Sugiono, 2010:408) sebagai berikut:

1. Potensi dan Masalah 
Potensi adalah segala sesuatu yang bila didayagunakan akan memiliki nilai tambah. Kertas, kardus adalah benda yang sering ditemui oleh anak-anak, di buku mereka atau kemasan snack dan jajanan mereka. Kardus dan kertas akan lebih memiliki nilai kebermaknaan bila dikombinasikan dengan gambar-gambar yang yang disukai oleh anak-anak.

Gambar merupakan bentuk karya yang sering ditemui dan akrab dengan anak-anak, sebuah gambar akan lebih berguna saat didalamnya terdapat pembelajaran dan penanaman sikapsikap yang positif. Dengan sedikit sentuhan kreatif maka sebuah gambar dapat dijadikan media pembelajaran yang menyenangkan bagi anak-anak dan mempermudah guru untuk menyampaikan materi dengan lebih variatif lagi.

Masalah adalah penyimpangan antara yang diharapkan dengan yang terjadi. Setelah dilakukan penelitian secara langsung di TKK Santo Yusuf Kota Madiun, ada beberapa masalah terkait dengan pembelajaran bercerita. Kurangnya media pembelajaran untuk memperkenalkan budaya bangsa kepada para siswa, dan para guru sangat menyayangkan bahwa anak-anak didiknya lebih mengenal tokoh dari filmfilm luar negeri.

2. Mengumpulkan Informasi
Dalam tahap ini diperlukan metode penelitian tersendiri. Metode apa yang akan digunakan untuk penelitian tergantung permasalahan dan ketelitian tujuan yang ingin dicapai. Informasi yang telah terkumpul dapat digunakan sebagai bahan untuk perencanaan produk tertentu yang diharakan dapat mengatasi masalah tersebut. Dari beberapa masalah yang ditemui di sekolah pada penelitian awal, maka tujuan yang ingin dicapai dari penelitian ini adalah membuat media pembelajaran yang dapat digunakan oleh para guru untuk menyampaikan materi berupa cerita dan mampu membangun jiwa nasionalisme serta menciptakan suasana belajar yang menyenangkan bagi siswa TKK Santo Yusuf Kota Madiun.

3. Desain produk Langkah-langkah yang harus dilakukan peneliti dalam membuat produk yang dikembangakan sebagai berikut:

a. Menentukan bentuk media

Sesuai dengan tujuan pembuatan media yang digunakan untuk membangun jiwa nasionalisme serta menciptakan suasana belajar yang menyenagkan, maka peneliti nmenggunakan media yang berupa wayang yang memiliki spesifikasi sebagai berikut:

1) media WEDUS GEMBEL (Wayang Kardus Gembira dan Belajar) 
a) Bahan Dasar : Kertas poster, kardus dan gambar wayang kartun, stik bambu.

b) Bentuk media: Menyesuaikan tokoh wayang.

c) Ukuran Media: Menyesuaikan bentuk wayang.

d) Gambar: Tokoh Pandawa.

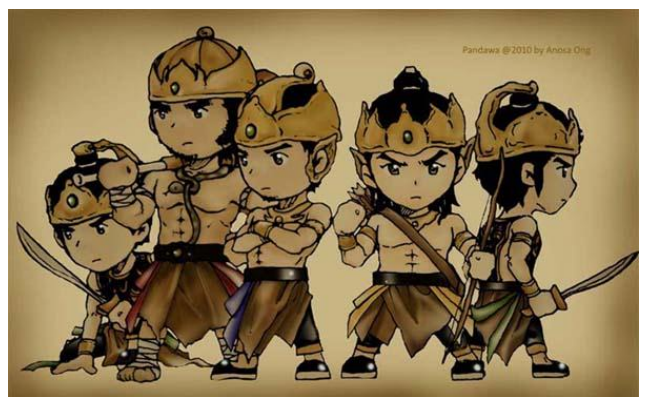

Gambar 4.1 Tokoh Pandawa

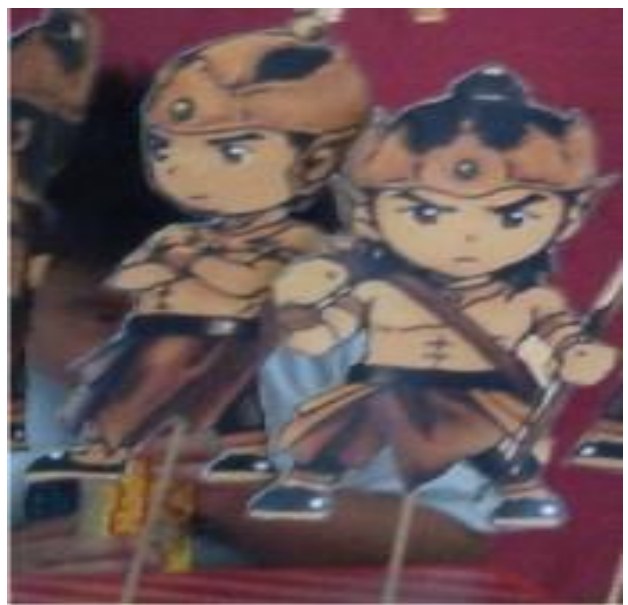

Gambar 4.2 WEDUS GEMBEL

(Wayang Kardus Gembira dan Belajar)

4. Validasi Desain

Pada tahap valididasi desain ini, peneliti melaksanakan beberapa tahapan sebagai berikut:

a. Mengajukan rancangan produk kepada validator untuk di validasi.

Rancangan produk awal diserahkan oleh peneliti kepada validator untuk di validasi. Validasi dilakukan dengan memberikan lembar validasi media WEDUS GEMBEL (Wayang Kardus Gembira dan Belajar) kepada validator untuk menilai secara langsung rancangan produk. Hasil validasi media WEDUS GEMBEL (Wayang Kardus Gembira dan Belajar) dapat dilihat sebagai berikut:

\begin{tabular}{|l|l|l|l|}
\hline No. & \multicolumn{1}{|c|}{ Validator } & $\begin{array}{l}\text { Skor } \\
\text { kelaya- } \\
\text { kan }\end{array}$ & \multicolumn{1}{|c|}{$\begin{array}{c}\text { Kriteria } \\
\text { kelayakan }\end{array}$} \\
\hline 1 & \multicolumn{1}{|c|}{2} & 3 & 4 \\
\hline 1 & $\begin{array}{l}\text { Drs.Soebijantoro, } \\
\text { MM, M.Pd }\end{array}$ & 83,3 & Layak \\
\hline 2 & $\begin{array}{l}\text { Dr. Muhammad. } \\
\text { Hanif., M.Pd }\end{array}$ & 86,7 & ELayak \\
\hline 3 & $\begin{array}{l}\text { Agnes Fitri } \\
\text { Haryani, S.Pd, AUD }\end{array}$ & 96,7 & ELayak \\
\hline & Rata-rata & 88,8 & ELayak \\
\hline
\end{tabular}

Tabel 4.3 Tabel Hasil Validasi

Berdasarkan data hasil validasi dari validator, rata-rata skor kelayakan adalah 88,8 (Lampiran 6). Rata-rata tersebut menunjukkan bahwa media WEDUS GEMBEL (Wayang Kardus Gembira dan Belajar) yang dikembangkan sudah memenhi kriteria pengembangan dan memiliki kriteria sangat layak sebagai sebuah media pembelajaran yang dapat digunakan atau diujikan pada Siswa TKK Santo Yusuf Kota Madiun.

\section{Pembahasan Produk Akhir}

Penelitian yang telah dilakukan di SMA 3 Pati mengenai Pengembangan Media Pembelaajran Fisika Berbasis Animasi Komputer Dengan Macromedia Flash 8 
Untuk Sekolah Menengah Atas Pokok Bahasan Hukum Newton Tentang Gerak mendapat respon yang baik dari siswa dan dapat meningkatkan semangat belajar siswa pada pelajaran fisika.

Media WEDUS GEMBEL (Wayang Kardus Gembira dan Belajar) merupakan pengembangan media dengan konsep yang bisa dibilang sama dengan media Animasi Komputer Dengan Macromedia Flash 8, yaitu menciptakan media pembelajaran yang menyenangkan bagi siswa. Meskipun memiliki konsep yang sama namun tujuannya tetaplah berbeda, media WEDUS GEMBEL (Wayang Kardus Gembira dan Belajar) bertujuan untuk memperkenalkan budaya Indonesia dan juga menumbuhkan jiwa nasionalisme pada siswa melalui media wayang. Dari hasil validasi yang dilakkan oleh para validator mengenai kelayakan media WEDUS GEMBEL (Wayang Kardus Gembira dan Belajar) yang telah dikembangkan, di dapat nilai rata-rata skor 88,8. Dari nilai tersebut dapat dinyatakan bahwa media WEDUS GEMBEL (Wayang Kardus Gembira dan Belajar) sudah cukup layak untuk diujikan pada siswa TKK Santo Yusuf Kota Madiun Kelompok B3.

Pelaksanaan pembelajaran yang dilakukan di TKK Santo Yusuf Kota Madiun pada kelompok B3 setelah melalui uji validasi mendapatkan respon yang baik dari siswa. Data yang diperoleh dari lembar observasi yang diisi oleh kepala sekolah menunjukan bahwa siswa antusias mengikuti apa yang peneliti sampaikan di depan kelas. Dari data yang diperoleh pada 19 siswa yang ada dengan kriteria baik, maka media WEDUS GEMBEL (Wayang Kardus Gembira dan Belajar) dapat diterima dengan baik dan mampu memperkenalkan budaya Indonesia dan juga menumbuhkan jiwa nasionalisme pada siswa kelompok B3 Santo Yusuf Kota Madiun.

\section{Simpulan}

Berdasarkan hasil penelitian dan pembahasan, maka dari data yang telah diperoleh dapat disimpulkan bahwa media WEDUS GEMBEL (Wayang Kardus Gembira dan Belajar) yang diterapkan di TKK Santo Yusuf Kota Madiun pada Siswa Kelompok B3 pada pembelajaran bahasa dengan tema cerita yang telah dilakukan dengan beberapa langkah yang sebelumnya dilaksanakan penulis.

$$
\text { Langkah-langkah tersebut }
$$

antaralain pengmpulan data/ Informasi, Analisis potensi dan masalah, pembuatan produk (media), Uji coba produk dan validasi dari yang dilakukan oleh 3 Validator. Penilaian yang diberikan oleh ketiga validator menunjukan nilai rata-rata 88,8, dari nilai tersebut maka media WEDUS GEMBEL (wayang Kardus Gembira dan Belajar) dapat diujicobakan pada kelas yang lebih besar.

Berdasarkan hasil uji coba yang dilaksanakan oleh peneliti di TKK Santo Yusuf Kota Madiun pada Siswa Kelompok B3 mendapatkan respon yang sangat baik 
dari para Siswa. Hal ini ditunjukkan dengan nilai yang berada antara 60-100, yang mana 4 anak mendapat nilai antara 61-80 dengan kriteria baik, dan 15 anak sisanya mendapat nilai 81-100 dengan kriteria sangat baik. Dari data yang diperoleh baik dari Validator dan respon siswa, menunjukkan bahwa media WEDUS GEMBEL (wayang Kardus Gembira dan Belajar) layak digunakan sebagai sebuah media untuk diterapkan pada pembelajaran bercerita sekaligus dapat digunakan sebagai saran pengenalan budaya dan pengembangan jiwa nasionalisme pada anak.

\section{Implikasi Media Pembelajaran}

Berdasarkan uji coba lapangan yang telah dilakukan, terdapat beberapa implikasi yang muncul, antaralain:

1. Implikasi terhadap kegiatan pembelajaran

Kegiatan pembelajaran berceria dengan menggunakan media WEDUS GEMBEL (Wayang Kardus Gembira dan Belajar) mampu menciptakan suasana belajar yang menyenangkan dan meningkatkan semangat belajar siswa serta dapat memperkenalkan budaya Indonesia dan mampu mengembangkan jiwa nasioanalisme pada diri siswa.

2. Implikasi terhadap pendidik

Penelitian dan pengembangan media WEDUS GEMBEL (Wayang Kardus Gembira dan Belajar) dapat dijadikan sebagai sebah media penyampaian pembelajaran oleh para pendidik, serta memberikan refrensi akan media pembelajaran yang dapat memotivasi para pendidik untuk berani berinovasi dan lebih kreatif untuk menciptakan suasana pembelajaran yang menyenagkan dan berkualitas bagi para siswa.

\section{Saran}

Berdasakan hasil penelitian dari pengembangan media WEDUS GEMBEL (Wayang Kardus Gembira dan Belajar), peneliti hanya dapat memberikan saran, sebagai berikut:

1. Bagi Guru

Guru sebagai tenaga pendidik seharusnya dapat menciptakan mediamedia yang dapat merangsang keingintahuan siswa tentang apa yang disampaikan. Pembelajaran tradisional dan konvensional nampaknya kurang tepat lagi jika disampaikan untuk siswa sekarang. Media pembelajaran akan lebih mengena pada para siswa jika dibandingkan dengan cara mengajar yang hanya bercerita saja, dengan demikian akan tercipta suasana belajar yang menyenangkan.

2. Bagi Peneliti Lain

Peneliti selanjutnya, sangat diharapkan untuk dapat menciptakan dan mengembangkan media yang lebih menarik dan inovatif, sehingga suasana belajar bisa menyenangkan dan lebih berkualitas bagi para siswa. Untuk 
menciptakan media yang tepat sasaran dan sesuai dengan potensi dan masalah, maka akan lebih baik jika melaksanakan uji coba prodk terlebih dahulu sebelum diperkenalkan sebagai sebuah media pada kelas besar. Jika media telah bisa dikatakan layak, maka alangkah lebih baiknya penegmbangan media hingga pembuatan produk masal.

\section{Daftar Pustaka}

Aman. 2011. Model Evalausi Pembelaaran Sejarah. Yogyakarta: Penerbit Ombak

Yudhi Munadi. 2008. Media Pembelajaran (Sebuah Pendekatan Baru). Ciputat: Gaung Persada (GP) Press
Azhar Arsyad. 2011. Media Pembelajaran. Jakarta: PT Raja Grafindo Persada

http://library.ikippgrismg.ac.id/docfiles/ful ltext/7a8879ba4fb4eaec.pdf

Isjoni. 2011. Model pembelajaran anak Usia Dini.Bandung: Alfabeta

Joko Subagyo. 2004. Metode penelitian dalam Teori dan Praktek Yogyakarta : Rineka Cipta.

Smith, Anthony D. 2003. Nasionalisme Teori,Ideologi,Sejarah . Jakarta: Erlangga

Sugiyono. 2010. Metode penelitian Pendidikan (Pendekatan Kuantitatif, Kualitatif, dan R\&D. Bandung: Alfabeta

team laboratorium pancasila IKIP Malang.2002. Refkeksi pancasila dalam Pembangunan. Surabaya: laboratorium pancasila IKIP Malang dan Usaha Offset 